\title{
Impact of External Debt on Economic Growth in Brazil: An ARDL Bound Testing Approach
}

\author{
Brezilya'da Diş Borçların Ekonomik Büyüme Üzerindeki Etkisi: ARDL Sinir \\ Testi Yaklaşımı
}

\begin{abstract}
For developing countries, sustainable economic growth is one of the key macroeconomic objective. However not every country has enough capital to support GDP growth. Even that the country hasn't enough national capital, the government can borrow some capital as external debt to support GDP growth. The aim of this study is to investigate the relationship between economic growth and external debt fort he Brazilian economy. In this study, the effect of various variables such as the ratio of external debt to GDP, ratio of debt service stock to GDP, the ratio of national expenditure to GDP, real Exchange rate, trade openness were investigated in the long run and short run. Accordingly, the effect of external debt on economic growth was determined with the help of ARDL Bound Test. The data used in the study covers the period of 1970-2015. Acording to the findings, a long-term relationship was found between external debt and growth rate in Brazil. It was concluded that external debt had a negative effect on the economic growth. According to this result, it is thought that developing countries external borrowing, providing sustainable debt and converting debt into investments will increase the GDP.
\end{abstract}

\section{Öz}

Gelişmekte olan ülkeler için sürdürülebilir ekonomik büyüme kilit makroekonomik hedeflerden biridir. Ancak her ülkenin GSYH büyümesini destekleyecek kadar sermayesi yoktur. Ülkenin yeterli ulusal sermayesi olmasa bile, hükümet GSYH büyümesini desteklemek için bir miktar dış borç olarak borç alabilir. Bu çalışmanın amacı Brezilya ekonomisindeki ekonomik büyüme ve dış borç arasındaki ilişkiyi incelemektir. Bu çalışmada, uzun ve kısa vadede dış borcun GSYH'ye oranı, borç hizmet stokunun GSYH'ye oranı, milli harcamaların GSYH'ye oranı, reel döviz kuru ve dışa açıklık değişkenlerin ekonomik büyümeye etkisi araştırılmıştır. Buna göre, dış borcun ekonomik büyüme üzerindeki etkisi ARDL Sınır Testi yardımıyla belirlenmiştir. Araştırmada kullanılan veriler 1970-2015 dönemini kapsamaktadır. Bulgulara göre, Brezilya'da dış borç ile büyüme oranı arasında uzun vadeli bir ilişki bulunmuştur. Dış borcun ekonomik büyüme üzerinde negatif etkisi olduğu sonucuna varılmıştır. Bu sonuca göre, gelişmekte olan ülkelerin dış borçlanmasının, sürdürülebilir borç sağlanmasının ve borçların yatırımlara dönüştürülmesinin GSYH'yi artıracağ̊ düşünülmektedir.

\section{Introduction}

One of the key macroeconomic objectives of a nation is the achievement of sustainable economic growth. To achieve this goal, every government requires a substantial amount of capital finance though investment expenditures on infrastructural and productive capacity development (Umaru et al, 2013). As a result the growth of their gross domestic product (GDP) is a key for the development. However if the country haven't enough finance capacity, government can borrow to keep on growing.

Borrowing to promote economic growth is the way governments refer for sustainable growth. To create trigger environment for people to invest in various sector of their economies, governments should invest infrastructure investments. Obudah and Tombofa (2013) argued what the reasons for the borrowing of the countries included. Among these reasons is the ability to finance increased

\author{
Tuğba Koyuncu \\ Üniversitesi, İsletme ve Yönetim \\ Bilimleri Fakültesi, Havacılık \\ Yönetimi Bölümü \\ Orcid: 0000-0002-2721-1313
}

\section{Hüseyin Demirhan}

Üniversitesi, İktisat Politikası Bölümü

huseyindemirhan@nevsehir.edu.tr

Article Type / Makale Türü

Anahtar Kelimeler

Testi Yaklaşımı, Brezilya

Boundary Testing Approach, Brazil

Submitted: 14 / $01 / 2020$

Accepted: 13 / 10 / 2020
External Debt, Economic Growth, ARDL 
government expenditures, to finance budget expenditures and to increase production. If the government want faster growth rate, it can barrow more and more but barrowing also has risky aspects. If the government borrow much than it can pay back, this will lead the economy risky and unstable. As a result of borrow more than government can pay, can lead to crises that can negative effect on growth rate and economic structure.

Brazil covers a wide geography starting from the middle of the South American continent to the Atlantic Ocean. Neighbors are from south to north: Uruguay, Argentina, Paraguay, Bolivia, Peru, Colombia, Venezuela, Guyana, Suriname, French Guyana. It covers a large part of the South American continent has a long coast to the Atlantic Ocean. It is a neighbor to all countries except for Ecuador and Chile which are located in South America due to Brazil's large territory. As the 9th word largest economy is Brazil also $5^{\text {th }}$ in terms of population. Brazil's population is about 207.6 million and the GDP of the Brazilian economy is about 1.796 (\$) trillion. As one of the largest economy and populations Brazil is the one of the most important country the World in point of economy. Therefore, in this study we will work on impact of external debt on economic growth in Brazil.

Purpose of the study is to reveal relationship between economic growth and external debt. In this study we will use The ARDL bound testing approach to cointegration and error correction models for the periods 1970-2015; In order to investigate the existence of long-run equilibrium relationship among variables (Stella Ada et all, 2016). Variables to study with are; GDPGR (annual growth rate of real GDP), EDS/GDP (ratio of external debt to GDP), DSS/GDP (ratio of debt service stock to GDP), NEXP/GDP (ratio of national expenditure to GDP), EXCH [real exchange rate (BRL/USD)], TRD (trade openness). This study consists of introduction, as the second chapter literature review, as the third chapter methodology, as the fourth chapter applied empirical method and data set, as the last chapter results and suggestions.

\section{Literature}

Inadequate national resources make it inevitable to borrow. External borrowing is particulary important for under developed and developing countries. Therefore the effect of external debt on economic growth have been studied and discussed by many researchers. Babic and Primorac(1986) in the study on the Yugoslavian economy the effects of variable such as total debt, consumption, investment and external debt on economic growth were examined. As a result of the study, it has been reached that the foreign debt has made the Yugoslavian economy dependent on the outsid. Geiger (1990) he has done a study on debt and economic growth in Latin American countries. He has made analyzes in different South American countries using real GDP growth rate, the ratio of net transfers to GDP, debt services, ratio of debt service to GDP data. For most countries the result support the that the marginal effect of the debt burden on the economy decrease as a debt burden increases. Many countries adapt to an increasing debt burden and learn ways to manage the problems involved in servicing a large debt.

Wijnbergen (1991) he did research on Mexico and as a result of the study, the increase in external debt caused an increase in inflation rates. Mexico needs to be more cautious in order to have a positive impact on growth in foreign debt. Wally and Tamaschke (1994) he conducted a survey on the countries of northern Africa (Algeria, Egypt, Morocco) with the years 1975-1989. The study concluded that the level of heavy debt in the three African countries would have a negative impact an economic growth. Singh (1999) in his study of India, analyzed the Granger Causality test and consequently Granger Causality show no relationship between the series.

Chaudhary et al. (2001) they have studied the effect of foreign debt on economic growth on South Asian countries( Pakistan, India, Bangladesh, Nepal, Sri Lanka, Maldives, Bhutan). As a result of the study, it has been found that the external debts of the southern Asian countries have a accumulated at an unsustainable rate. It was seen that external debt negatively affected growth. Kraay and Nehru (2006) they have worked with a total of 93 countries as low-income and middleincome. They used such as real exchange changes, real GDP growth, total debt variables. The results indicates that the probablity of debt distress is already high in many low-income countries and is 
likely to increase sharply if the large scale development finance required to meet the Millennium Development Goals is provided in the form of consessional lending at historical.

Sen et al. (2007), they was examined two different groups as Latin American countries( Arjantine, Brazil, Colombia, Mexico, Venezuela) and Asian countries(China, India, Indonesia, Philippines, South Korea and Thailand). In the Panel Data Analysis, the following variables were used: per capita of GDP, ratio of debt to GDP, ratio of debt service to exports, ratio of capital stock to GDP, total labour force, external debt to export. The study has reached the conclusion that borrowing in Latin America affects growth considerably. The negative impact of debt stock on GDP growth seems robust. Similarly, for Asian countries, borrowing has also had a negative impact on growth. But this effect is less.

Jayaraman and Lau (2009), in the study they have conducted, the impacts on the external debt and economic growth of the Pasific countries are investigated. Panel performed the unit root test. Then they did Granger causality analysis. According to empirical studies, foreign debt, budget deficit and exports are additionally causal linkages in the short run, although there is no long-run relationship between external debt and growth. Between econmic growth and the external debt, a short-term dual causality was found. Uysal et al.(2009) in the study, the relationship between external debt and economic growth was investigated trough Augment Dickey Fuller Test(ADF) and Phillips-Peron (PP) unit root test, Vector Autoregressive Model(VAR), cointegration and Granger Causality analysis. The findings of the study showed that external debt in short and long run affected the economic output level negatively.

Greenidge et al.(2010) the study was based on the external borrowing of CARICOM countries. This paper also results indicates that some of the time period required to achieve this target are too long, given the assumed parameters, but it is expected that with greater fiscal effort and more growth in output these period can be shortened considerably. Akram(2011) his study examined the effect of debts in the Pakistani economy with data from 1992 and 2006 using external debt stock, export, import, investment and openness data. ADF unit root test, ARDL and VECM tests were applied for this purpose. As a result of the study, there is a negative correlation between external debt and GDP per capita in both short term and long term in Pakistan.

Muhanji and Ojah(2011) they have worked with countries like Cote'Ivoire, Ghana, Kenya, Malawi, Nigeria, Senegal, South Africa, Tanzania, Uganda, Zambia and Zimbabwe. They made analyzes using external debt, imported investments, inflation, consumption imports, interest rate, exchange rate, exports and output variables. According to results show that both world commodity price and world interest rate shock impact external debt accumulation in the majority of African countries. Interestingly, world commodity price shocks lead to an increase in external debt while world interest rate shocks appear to discourage accumulation of external debt.

Butts et al.(2012) using short term external debt and real GDP growth data for 1970-2003, they examined the impact of short-term external debt on economic growth. In this context, ADF and PP unit root tests, ARDL Boundary Test and Granger Causality Analysis were done. Results there is indirect Granger Causality from economic short term external debt for the consumption effects. There is a evidence that economic exhange rate and international reserves are determinents of shortterm external debt.

Ali and Mustafa(2012) they have used annual data for 1970-2010 in their studies on Pakistan. In the study, ADF unit root test, Johansen cointegration test and finally Vector Error Correction Model(VECM) were used. Gül et al.(2012) they used various test by obtaining 6 different Turkish Republic's(Azerbaijan, Kazakhstan, Kyrgyzstan, Uzbekistan, Tajikistan, Turkmenistan) 1994-2010 data. As a result of the analyzes, one-way causality was found to growth from long-term external debt. Afonso and Jalles(2013) he conducted a survey on 155 OECD countries using 1970 and 2008 data. The higher the level of borrowing as a result of the study, the greater the economic growth for the OECD countries.

Panizza and Presbitero(2014) as a result of their work show a negative relationships between debt and growth. However, this relationships between debt and growth can be lost by correcting intrinsic value. Doğan and Bilgili(2014) they investigated the effect of foreign debts on economic 
growth in Turkey using 1974-2009 data. In the study they used invesment, human Capital, openness, population, growth of GDP, ratio of private external debt to GDP and ratio of public external debt to GDP variables. According to result of the main growth variables such as investment and human capital have positive impact on growth as a expected. As a result, economic growth and growth variables did not follow a linear path.

Ramzan and Ahmad(2014) they have studied the 1970-2009 data of Pakistan in their work on external debt on economic growth. ADF, PP unit root test and ARDL Boundary test were performed by using external debt and growth of GDP data. The results show that external debt has a negative impact on growth, but this adverse effect can be reduced or even reversed in the presence of sound macroeconomic policy. Bal and Rath(2014) they have done research on debts and economic growth on the Indian economy. The following variables were used in the study: economic growth, domestic debt, external debt, debt service, export, total factor productivity. In their study, the result from the ARDL model show that there is a long run equilinrium relationship between variables. In the Error Correction Model(ECM), it is seen that all variables affect economic growth in the short run and these results are consistent with a predicted expectation.

Teles and Mussolini(2014) the data of 74 countries are used in the study they have done. The following variables were used in the study: economic growth, GDP, investment as a percentage of GDP, trade, inflation, debt to GDP ratio. Casares(2015) in his work he explored the relationship between external debt and economic growth. As a result of the study, it has been found that external debt affects economic growth positively.

Spilioti and Vamvouskas(2015) between 1970 and 2013, they used growth rate of GDP, government debt, the gross domestic product per head of population, the gross national saving, the sum exports of goods and services, the sum import of goods and services data and examined the impact of government borrowing on economic growth for the Greek economy. The empirical results suggest a positive and statistically significannt impact of debt on GDP growth. Puig and Rivero(2015) they tested the relationship on debt and growth with Granger causality analysis. In the study EMU countries (Greece, Ireland, Italy, Portugal, Spain, Austria, Belgium, Finland, France, Germany) data between 1980 and 2013 were used. The result of evidence is presented on the possible existence of bi-directional casual relationship between public debt and economic growth in both central and peripheral countries of the European Economic and Monetary Union.

Godwin et al.(2016) they investigated the impact of foreign debt on growth on the Nijerian economy. They used annual growth rate of real GDP, ratio of external debt to GDP, ratio of debt service stock to GDP, ratio of national expenditure to GDP, exhange rate and trade openness data in the study. First ADF and PP unit root tests were performed. Later ARDL Boundary test was performed and Granger Causality Analysis was performed to determine whether there was a causal relationship between the variables. The resault of this study indicates a long-run relationship among the variables and external debt impacts negatively significant on output. The findings also established a unidirectional causality between external debt and economic growth.

Ushahembaljirshar et al.(2016) similarly, they worked on the Nigerian economy. However they have examined the relationship between the national debt and economic growth. They used the data of 1981-2014 in the study. ADF unit root test, Granger Causality and Johansen Cointegration analysis were applied. The results of all the variables were not stationary at level but achieved stationary after first diffrence at $\% 5$ level of significance. The regression result showed e significant relationship between external debt and economic growth in the Nigeria. However, external debt stock impacted positively while external debt service impacted negatively on the annual growth rate of the Nigerian economy both in the long run and the short run.

Siddique et al.(2016) they have worked on economies of 40 countries that are heavily indebted. Six different panel unit root test were performed and then the effects of external forces on economic growth was investigated by the ARDL test. According to approach GDP and mercandise export growth accelerated fastest since 2000, while debt levels have fallen since 2000. The estimation results indicate firstly that, capital formation's share of GDP has positive impact on HIPC's GDP in the short run as well as long run. Secondly, debt as a share of GDP has a negative influence in the short run 
as well as in the long run. Thirdly, in the long run the mercandise trade as a percentage of GDP has a positive influence on GDP.

Karagöz and Çağlar(2016) they conduced a panel unit root test with data from 17 OECD countries. Overall result of study shows that for the OECD countries the foreign debt and growth relationships is a positive one. Although there are some countries in the world that have a negative relationship, for the case of OECD at least, positive relationships are indicative of good policy administration. Chen et al.(2016) they have studied 65 developed and developing county economies. As a result of their work, the effect of government investment on economic growth was seen to decrease as the level of borrowing increased. Similarly, if the size of the public debt stock increases especially when the public debt to GDP ratio is higher than $\% 59,72$, the effect of public debtors on economic growth is reduced and positive result turns out to be negative effect.

Semmler and Tahri(2017) using data from 1998-2012, they heve studied on the economy of Italy, Spain and Germany. As a result of their work, they have reached a slow-moving debt criss in the other two economies but for Germany this findings is not valid. Puig and Rivero(2017) they used variables such as real growth rate, level of output, public debt to GDP ratio, population growth, human capital, openness and inflation. The result show that debt in all countries outside Belgium is beginning to have negative effects on growth. Also, if the consequences indicates that the detrimental effect of a debt change on growth does not have the same intensity and intensity across all Economic and Monetary Union (EMU) countries, focusing on average rates and impacts may not be appropriate for defining policies. In particular, findings show that the rate of fiscal regulation in Greece and Spain should be lower than in other countries.

Musibau et al. (2018) examined the relationship of external debt with economic grpwth in the countries of the Economic Community of West African Countries (ECOWAS). As a result of their study using the data of 1980-2015 period, a causal relationship was determined from foreign debts to economic growth in both the long term and the short term. Kharusi and Ada (2018), analyzed the 1990-2015 period data using the ARDL method to determine the impact of external debt on economic growth in Oman. The results show that external debt negatively affected economic growth in Oman during the period in question.

Gövdeli (2019), investigated the impact of external debt, openness and consumer price index on economic growth using data from the 1970-2016 period. According to the findings obtained from the study using ARDL merhod in Turkey it has a positive impact of external debt on economic growth. Edo et al. (2020), investigated the relationship between external debt and exports with economic growth in sub-Saharan African countries esing 2005:Q1-2017:Q4 period data. The results showed that external debts positively affected economic growth in the period in question.

Table 1. External Debt and Economic Growth Relationship Literature Summary

\begin{tabular}{|c|c|c|c|c|}
\hline Author(s) & Period & Countries & Methodology & Conclusion \\
\hline Geiger(1990) & $1974-1986$ & $\begin{array}{l}\text { Latin American } \\
\text { Countries }\end{array}$ & $\begin{array}{l}\text { Ordinary Least Square } \\
\text { (OLS) }\end{array}$ & Negative \\
\hline $\begin{array}{l}\text { Wally and } \\
\text { Tamaschke (1994) }\end{array}$ & 1975-1989 & $\begin{array}{l}\text { Algeria, Egypt, } \\
\text { Morocco }\end{array}$ & $\begin{array}{l}\text { Ordinary Least Square } \\
\text { (OLS) }\end{array}$ & Negative \\
\hline Sen et al.(2007) & $1970-2000$ & $\begin{array}{l}\text { Latin American } \\
\text { Countries }\end{array}$ & $\begin{array}{l}\text { Pooled Ordinary Least } \\
\text { Squares (POLS) }\end{array}$ & Negative \\
\hline $\operatorname{Akram}(2011)$ & 1992-2006 & Pakistan & $\begin{array}{l}\text { ARDL, VECM Causality } \\
\text { Test }\end{array}$ & Bidirectional Casual Relationship \\
\hline Butts et al.(2012) & $1970-2003$ & Pakistan & $\begin{array}{l}\text { ARDL Bound Test, } \\
\text { Granger Causality } \\
\text { Analysis }\end{array}$ & External ebt $=>$ economic growth \\
\hline $\begin{array}{l}\text { Doğan and Bilgili } \\
\text { (2014) }\end{array}$ & 1970-2009 & Turkey & $\begin{array}{l}\text { Ordinary Least Square } \\
\text { (OLS) }\end{array}$ & Positive \\
\hline $\begin{array}{l}\text { Ramzan and Ahmad } \\
\text { (2014) }\end{array}$ & 1970-2009 & Pakistan & ARDL & Negative \\
\hline Bal and Rath(2014) & $1980-2011$ & India & ARDL & Positive \\
\hline $\begin{array}{l}\text { Spilioti and } \\
\text { Vamvouskas(2015) }\end{array}$ & $1970-2013$ & Greece & $\begin{array}{l}\text { Ordinary Least Square } \\
\text { (OLS) }\end{array}$ & Positive \\
\hline $\begin{array}{l}\text { Puig and Rivero } \\
\text { (2015) }\end{array}$ & $1980-2013$ & EMU & Granger Causality & Bidirectional Casual Relationship \\
\hline
\end{tabular}




\begin{tabular}{|c|c|c|c|c|}
\hline $\begin{array}{l}\text { Ushahembaljirshar } \\
\text { et al. (2016) }\end{array}$ & $1981-2014$ & Nigeria & $\begin{array}{l}\text { Granger Causality, } \\
\text { Johansen Cointegration }\end{array}$ & Negative \\
\hline $\begin{array}{l}\text { Puig and Rivero } \\
\text { (2017) }\end{array}$ & $1980-2015$ & EMU & $\begin{array}{l}\text { Ordinary Least Square } \\
\text { (OLS) }\end{array}$ & Negative \\
\hline Musibau et al. (2018) & 1980-2015 & ECOWAS & Causality Test & External debt $=>$ economic growth \\
\hline $\begin{array}{l}\text { Kharusi and Ada } \\
\text { (2018) }\end{array}$ & $1990-2015$ & Oman & ARDL & Negative \\
\hline Gövdeli (2019) & 1970-2016 & Turkey & ARDL & Positive \\
\hline Edo et al. (2020) & 2005:Q1-2017:Q4 & $\begin{array}{l}\text { Sub-Saharan } \\
\text { African }\end{array}$ & Causality Test & Positive \\
\hline
\end{tabular}

\section{Data and Methodology}

In the study, while the annual growth rate in GDP is used as a dependent variable, real change rate, the ratio of external debt stock to GDP, the ratio of external debt to GDP, the ratio of national expenditures to GDP, trade openness are included in the model as independent (explanatory) variables. This data used in the study consisted of 46 observations between 1970-2015 and all data used were obtained from The World Data Bank system. The reason for choosing this period range in the model is due to the fact that all data belonging to Brazil is collected on a common ground in the period 1970-2015. The ARDL Bound Test was applied to investigate the effects of foreign debt ratios and other variables on economic growth and analyzed by using Eviews program for this propose.

Using the obtained data, the model is formulated as follows:

$$
\begin{aligned}
\operatorname{InGDPGR}_{t}= & b_{0}+b_{1} \operatorname{InEDS} / G D P_{t}+b_{2} \operatorname{InDSS} / G D P_{t}+b_{3} \operatorname{InNEXP} / G D P_{t}+b_{4} \operatorname{InEXCH}_{t}+b_{5} \operatorname{InTRD}_{t} \\
& +u_{t}
\end{aligned}
$$

Data used in the application is coded as follow:

GDPGR: Annual Growth Rate of Real GDP

EDS/GDP: Ratio of External Debt to GDP

DSS/GDP: Ratio of Debt Service Stock to GDP

NEXP/GDP: Ratio of National Expenditure to GDP

EXCH: Real Exhange Rate

\section{TRD: Trade Openness}

In the model, the coefficients of $b_{1}, b_{2}, b_{3}, b_{4}$ and $b_{5}$ show the elasticity of the growth of with the variables such as external debt to GDP, ratio of external debt to GDP, ratio of national expenditures to GDP, real exhange rate and trade openness. Also $u_{t}$ indicates the error terms.

In this study, which investigated the long-term relationship between economic growth and external debt, the border test developed by Pesaran et al. (2001) was used. In case of some series level value and some of them in the first differences are stationary, autoregressive distributed lag model (ARDL) bound test approach is used to investigate existence of a long-run relationship between the variables. The ARDL model has many advantages. First, it prevents the occurrence of problems before the test, which is seen in conventional cointegration tests. Secondly, it permits the retrieval of a sufficient number of delays and facilitates the data generation process by means of the entire deriving method. According to traditional cointegration tests, this approach gives effective result in small volume samples. Finally, the dynamic error correction model (ECM) derived from the ARDL Bound Test combines short-circuited dynamics with long-running dynamics without causing information loss (Banerjee at al., 1993:51-52).

The test is used to test the statistical significance of delayed levels of variables in the conditional unrestricted equilibrium error correction model. The ARDL Bound Testing approach consists essentially of tree steps. In the first step, it is tested whether there is a long-term relationship between the variables involved in the analysis. Longitudinal and short-term elasticities are obtained in the presence of cointegration relation between the mentioned variables and in successive stages 
respectively (Narayan and Smyth, 2006:337). We adapted this model to the formula as follows by the adapting our study.

$$
\begin{aligned}
\Delta G D P G R_{t}=b_{0} & +b_{1} \Delta E D S / G D P_{t}+b_{2} \Delta D S S / G D P_{t}+b_{3} \Delta N E X P / G D P_{t}+b_{4} \Delta E X C H_{t}+b_{5} \Delta T R D_{t} \\
& +b_{6} G D P G R_{t-1}+b_{7} \Delta E D S / G D P_{t-1}+b_{8} \Delta D S S / G D P_{t-1}+b_{9} \Delta N E X P / G D P_{t-1} \\
& +b_{10} \Delta E X C H_{t-1}+b_{12} \Delta T R D_{t-1}+u_{t-1}
\end{aligned}
$$

The lag length test is constructed using delay length measures to obtain the optimal number of lag for each variable. This is followed by the prediction of an unlimited error correction model by a single equation with the number of selected delays, as shown in the equation 3.

$$
\begin{aligned}
\Delta G D P G R_{t}=b_{0} & +\sum_{i=1}^{a} b_{1} \Delta G D P G R_{t-i}+\sum_{i=1}^{a} b_{2} \Delta E D S / G D P_{t-i}+\sum_{i=1}^{a} b_{3} \Delta D S S / G D P_{t-i} \\
& +\sum_{i=1}^{a} b_{4} \Delta N E X P / G D P_{t-i}+\sum_{i=1}^{a} b_{5} \Delta E X C H_{t-i}+\sum_{i=1}^{a} b_{6} \Delta T R D_{t-i}+b_{7} G D P G R_{t-1} \\
& +b_{8} E D S / G D P_{t-1}+b_{9} D S S / G D P_{t-1}+b_{10} N E X P / G D P_{t-1}+b_{11} E{ } C H_{t-1}+b_{12} T R D_{t-1} \\
& +\varepsilon_{t}
\end{aligned}
$$

In the equation $\Delta$ is the first difference operator. The optimal lag length is $a$. All other variables remain the same. The Wald Test is obtained by applying $F$ statistics on the coefficient of unlimited $\varepsilon_{t}$ variables. F statistic are used to test the existence of a long-term relationship and are compared at the level of $\% 5$ significance. If the $\mathrm{F}$ statistics are above the upper boundary value, the null hypothesis that there is no cointegration between variables is rejected. However, if it falls below the lower bound value, the null hypothesis is accepted. If the F statistical values are within the bound values, the result is insufficient. If it is determined that there is a long cyclical relationship between variables, short-term dynamics can be derived predicting the $\varepsilon_{t}$ lags as specified. $\varepsilon_{t}$ is defined as error correction is the term 4 .

$$
\begin{aligned}
\varepsilon_{t}=\Delta G D P G R_{t} & -b_{0}-\sum_{i=1}^{a} b_{1}(G D P G R)_{t-i}-\sum_{i=1}^{a} b_{2}\left(\frac{E D S}{G D P}\right)_{t-i}-\sum_{i=1}^{a} b_{3}(D S S / G D P)_{t-i} \\
& -\sum_{i=1}^{a} b_{4}\left(\frac{N E X P}{G D P}\right)_{t-i}-\sum_{i=1}^{a} b_{5}(E X C H)_{t-i}-\sum_{i=1}^{a} b_{5}(T R D)_{t-i}
\end{aligned}
$$

\section{Emprical Results and Discussion}

First, the tendency of all variables was examined. When the graphs of the variables in Figure 1 are examined, it is seen that the variables such as growth in GDP, ratio of external debt stock to GDP, ratio of external debt to GDP and trade openness are not the trends. While the positive tendency of the exchange rate rises from a very low level to a peak level, the ratio of public expenditures to GDP is following a negative trend. The trends of all the variables used in this study before trading are as in the following Figure 1.

Figure 1. Graphs of Variables Included in the Model 
GDP growth (annual \%)
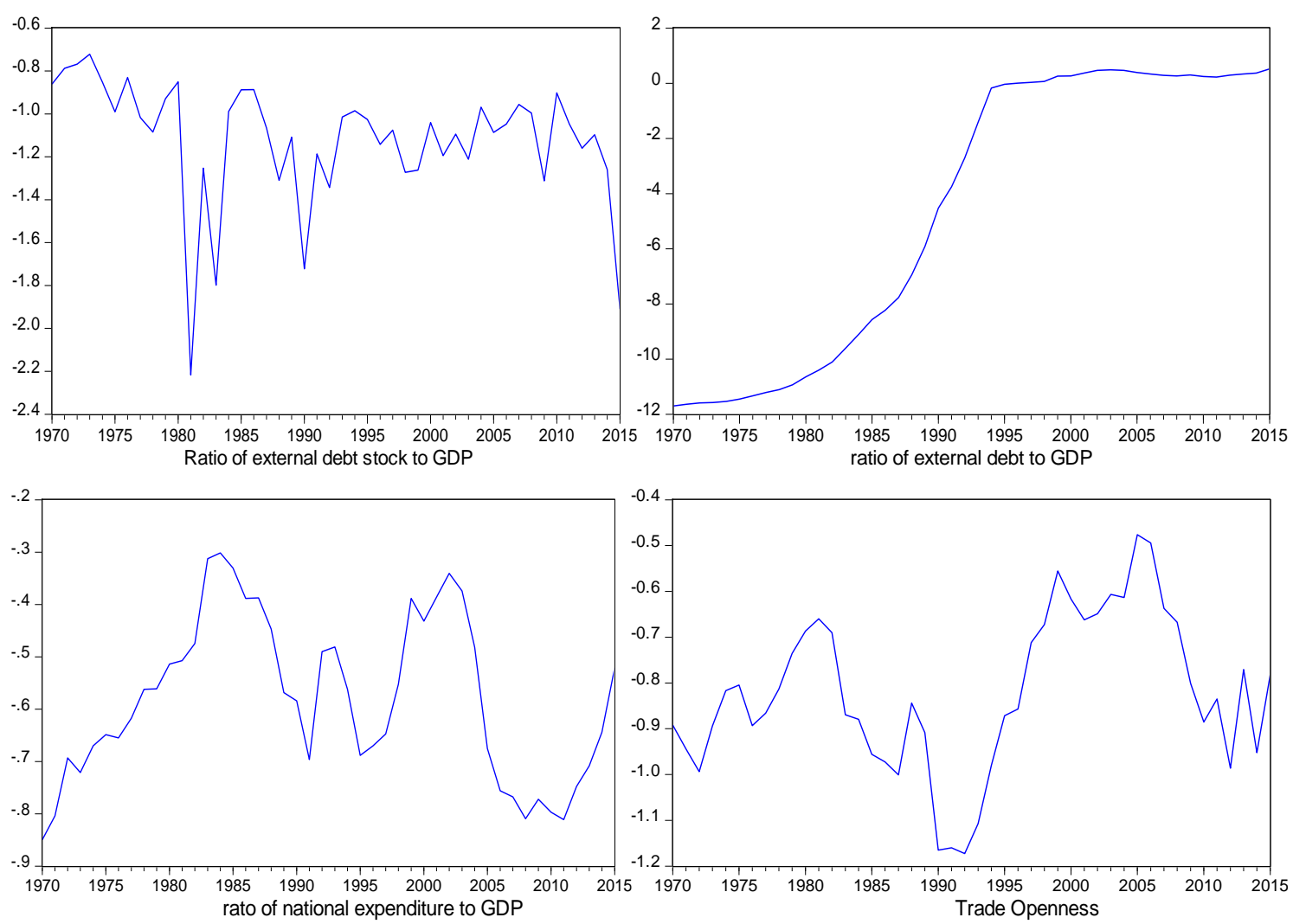
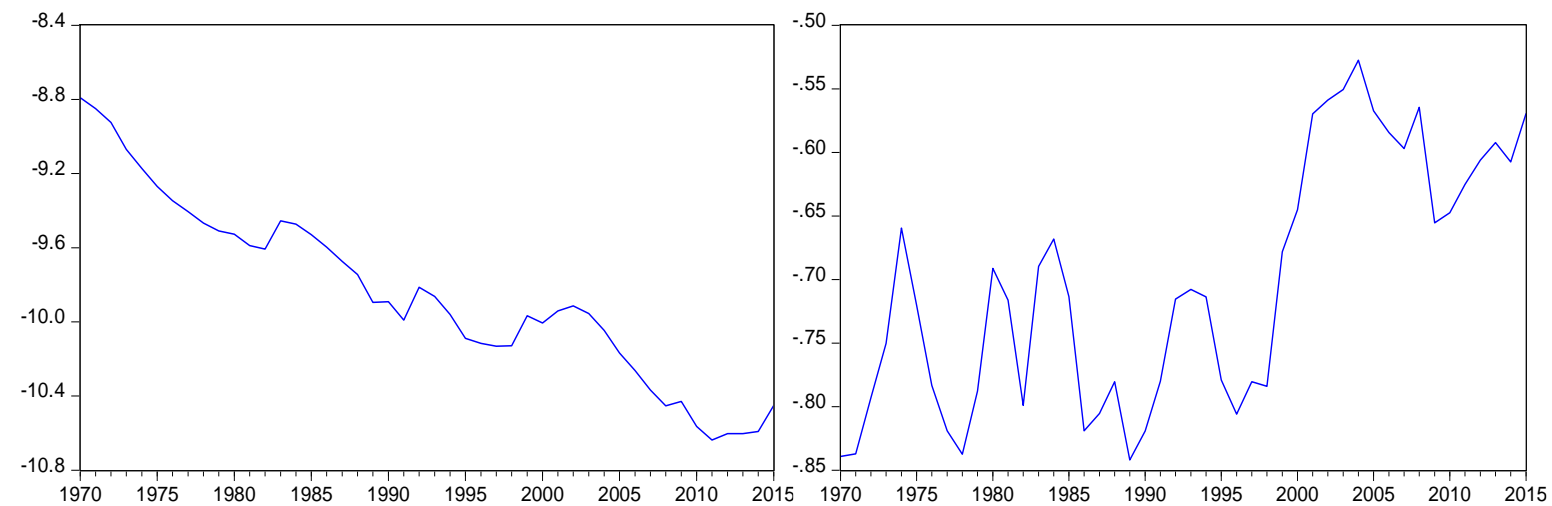

For all observations of the variance of the error term it is called heteroscedasticity situation is not the same. The variance of the conditional variance of the error term is a frequent problem especially in horizontal-cross sectional data analysis.

$$
\begin{aligned}
& H_{0}=\sigma^{2}(\text { constant variance }) \\
& \left.H_{1} \neq \sigma^{2} \text { (varying variance }\right)
\end{aligned}
$$

Null hypothesis indicates that variance is constant. The alternative hypothesis shows that variance is variable. Variable variance tests investigate that there is no correlation between the error term and the explanatory variables.

Table 2. Heteroscedasticity Test

\begin{tabular}{|l|c|c|}
\hline Heteroscedasticity Test & F-Statistic & Prob. \\
\hline Breusch-Pagan-Godfrey & 2,79 & 0,01 \\
\hline Harvey & 1,69 & 0,12 \\
\hline
\end{tabular}

When we look at the probability values, the variance problem in the Harvey test does not appear, but the variance problem varies according to the Breusch-Pagan-Godfrey test. Since the probability 
value in the Breusch,Pagan and GodfreyTest is $0,01<0.05, H_{0}$ hypothesis will be rejected and the residues at statistical significance level of 0.05 have varying variance. In the Harvey test, $H_{0}$ hypothesis is accepted as probability value is $0.05<0.12$. Statistically, at 0.05 significance leve have constant variance.

Table 3. Autocorrelation Test

\begin{tabular}{|c|c|c|c|}
\hline \multicolumn{4}{|c|}{ Breusch-Godfrey Serial Correlation Test } \\
\hline F-Statistic & 0,44 & Prob.F(2,32) & 0.64 \\
\hline $\begin{array}{c}\text { Obs*R- } \\
\text { squared }\end{array}$ & 1.69 & $\begin{array}{c}\text { Prob. Chi- } \\
\text { square(2) }\end{array}$ & 0,55 \\
\hline
\end{tabular}

The Table 2 above present the result of the Breusch-Godfrey test for autocorrelation. Table 2, prob.F 0,64 and Prob.Chi-square 0,55; it was determined that there was no autocorrelation problem.

Table 4. ARDL Long Run Form and Bound Test

\begin{tabular}{|l|c|c|c|c|}
\hline \multicolumn{5}{|c|}{ Conditional Error Correction } \\
\hline Variable & Coefficient & Std. Error & t-statistic & Prob. \\
\hline c & 3,991233 & 2,032269 & 1,963929 & 0,0578 \\
\hline GDPGR(-1)* & $-1,175732$ & 0,155154 & $-7,577862$ & 0,0000 \\
\hline EXCH(-1)* & 0,048562 & 0,018858 & 2,575192 & 0,0145 \\
\hline DSS/GDP** & $-0,007442$ & 0,377136 & $-0,019734$ & 0,9844 \\
\hline EDS/GDP** & $-0,829693$ & 0,349903 & $-2,271206$ & 0,0235 \\
\hline NEXP/GDP(-1) & 0,577298 & 0,210589 & 2,741355 & 0,0097 \\
\hline TRD** & 0,068175 & 0,568135 & 0,119998 & 0,9052 \\
\hline D(EXCH) & $-0,100458$ & 0,195385 & $-0,514152$ & 0,6105 \\
\hline D(EXCH)(-1) & $-0,320572$ & 0,211285 & $-1,517200$ & 0,1385 \\
\hline D(NEXP/GDP) & $-1,856572$ & 0,661322 & $-2,807363$ & 0,0082 \\
\hline
\end{tabular}

${ }^{*}$ p-value incompatible with t-Bounds distribution.

** Variable interpreted as $Z=Z(-1)+D(Z)$.

When the number of observations and annual data are taken into consideration, the maximum lag length is determined as 4 . This most appropriate lag length is determined using the Akaike Information Criteria (AIC) and Schwarz Information Criteria (SIC).

Table 5. ARDL Error Correction Regression

\begin{tabular}{|l|c|c|c|c|}
\hline \multicolumn{5}{|c|}{$\begin{array}{c}\text { ECM Regression } \\
\text { (Restricted Constant and No Trend) }\end{array}$} \\
\hline Variable & Coefficient & Std. Error & t-statistic & Prob. \\
\hline D(EXCH) & $-0,100158$ & 0,156099 & $-0,643553$ & 0,5242 \\
\hline D(EXCH)(-1) & $-0,320561$ & 0,173691 & $-1,845586$ & 0,0737 \\
\hline D(NEXP/GDP) & $-1,856557$ & 0,438382 & $-4,235057$ & 0,0002 \\
\hline CointEq(-1)* & $-1,175732$ & 0,135595 & $-8,670931$ & 0,0000 \\
\hline
\end{tabular}

* $\mathrm{p}$-value incompatible with $\mathrm{t}$-Bounds distribution

As shown in Table 4, the term CointEq(-1) error correction is negative. In the long run, a statistically significant relationship was found between the growth in GDP and the real exchange rate, the ratio of national expenditures to GDP.

Table 6. ARDL F-Bound Test \begin{tabular}{|l|l}
\hline Null hypothesis: No levels relationship & Critic Value \%1
\end{tabular} Critic Value $\% 5$ 


\begin{tabular}{|l|l|c|c|c|c|}
\hline $\mathrm{k}$ & F-Statistic & $\mathrm{I}(0)$ & $\mathrm{I}(1)$ & $\mathrm{I}(0)$ & $\mathrm{I}(1)$ \\
\hline 5 & 9,129612 & 3,06 & 4,15 & 2,39 & 3,38 \\
\hline
\end{tabular}

* $\mathrm{k}$ is the number of independent variables.

When Table 5 is examined, it is seen that the calculated F-statistic is bigger than the sub-critical value. Therefore, the basic hypothesis that there is no cointegration relation between variables is rejected.

\section{Conclusion}

Investigation of relationship between external debt and GDP growth rate, has begun with Keynes, who advocates that the government should intervene in the economy when necessary. The Keynesian school has argued that developing countries can make positive contributions when used to support external debt to growth. Harrod-Domar has shown that increasing income can be achieved by borrowing by investing. Taking these views into account, the external debt and growth rate relationship is deal with more extensively in later periods.

As a developing country, we have examined the relationship between borrowing and growth rate in Brazil with ARDL Bound Test for the period 1970-2015. We also applied Heteroscedasticity Test, Auto Correlation Test, ARDL Long Run Form and Bound Test, ARDL Error Correction Regression, ARDL F-Bound Test. As a result, in parallel with the literature, there was no short-run relationship between external borrowing and GDP growth, but a one-way relationship was found from long-term as external debt to GDP growth.

According to the long term coefficient estimation results of ARDL, $1 \%$ increase in the ratio of foreign debt to GDP causes a decrease of approximately $0,83 \%$ on real economic growth in Brazil. Similarly, in the studies of Uysal et al. (2009), Akram (2011), Puig and Rivero (2017), there was a long-term negative relationship between foreign debt and economic growth. These results show that economic growth was negatively affected if foreign debt increased in Brazil. According to the 2015 data based on the study, the ratio of foreign debt increases to gross national product in Brazil 30,8\%. When 2018 data are analyzed, this rate has decreases to $30.3 \%$. According to the findings obtained from this study, it is thought that channeling foreign debts to investments through the right sectors will positevely affect the national economy. It is thought that these sectors should be directed towards the country's potential and production of export products. Economic growth is considered to be negatively affected due to the fact that external debts are not converted into investments by using them efficiently. In the direction of the this result, it is recommended that developing countries use external debt to support GDP growth, by ensuring sustainable debt and by ensuring debts turn into investments.

\section{References}

Afonso A., Jalles J. T., (2013), "Growth And Productivity: The Role Of Government Debt", International Review Of Economics And Finance 25, 384-407

Akram N., (2011), "Impact Of Public Debt On The Economic Growth Of Pakistan", The Pakistan Development Review, Vol. 50, No. 4, Papers And Proceedings Parts I And I1 The 27th Annual General Meeting And Conference Of The Pakistan Society Of Development Economists Islamabad, December 13 - 15, 2011, Pp. 599-615

Alı R., Mustafa U., (2012), "External Debt Accumulation And Its Impact On Economic Growth in Pakistan", The Pakistan Development Review, Vol. 51, No. 4, Papers And Proceedings Parts I And I1 The 28th Annual General Meeting And Conference Of The Pakistan Society Of Development Economists Islamabad, November 13-15, Pp. 79-95

Babic M. And Primorac E. , (1986). "Some Causes Of The Growth Of The Yugoslav External Debt", Soviet Studies, Vol. Xxxviii, No. 1, January 1986, 69-88

Bal D.P., Rath B. N., (2014), "Public Debt And Economic Growth in India: A Reassessment", Economic Analysis And Policy 44, 292-300

Banerjee, A., Galbraith, J. Ve Hendry, D. (1993), Cointegration, Error Correction And Econometric Analysis Of Non-Stationary Data, Oxford University Press, Oxford. 
Butts H. C., Mitchell I., Berkoh A., (2012) “Economic Growth Dynamics And Short-Term External

Debt In Tharland", The Journal Of Developing Areas, Vol. 46, No. 1 (Spring 2012), Pp. 91-111

Casares E. R., (2015), "A Relationship Between External Public Debt And Economic Growth", Estudios Económicos, Vol. 30, No. 2 (60) Pp. 219-243

Chaudhary M. A., Anwar S., Tahir P., (2000), “Foreign Debt, Dependency, And Economic Growth İn South Asia", The Pakistan Development Review, Vol. 39, No. 4, Papers And Proceedings Part I1 Sixteenth Annual General Meeting And Conference Of The Pakistan Society Of Development Economists Islamabad, January 22-24, 2001, Pp. 551-570

Chen C., Yao S., Hu P. Lin Y., (2016), “Optimal Government Investment And Public Debt in An Economic Growth Model", China Economic Review

Dogan I., Bilgilı F., (2014) "The Non-Linear Impact Of High And Growing Government External Debt On Economic Growth: A Markov Regime-Switching Approach", Economic Modelling 39 213-220

Edo S., Osador N. E., Dading I. F., (2020) “Growing external debt and declining export: The concurrent impediments in economic growth of Sub-Saharan African countries", International Economics, Vol. 161, 173-187.

Geiger L. T., (1990), "Debt And Economic Development in Latin America", The Journal Of Developing Areas, Vol. 24, No. 2, Pp. 181-194

Gövdeli T., (2019), "External Debt and Economic Growth in Turkey: An Empirical Analysis", Socioeconomic, Vol. 27(40), 117-130.

Puig M. G., Rivero S., (2015), “The Causal Relationship Between Debt And Growth in Emu Countries", Journal Of Policy Modeling 37, 974-989

Puig M. G., Rivero S., (2017), "Heterogeneity in The Debt-Growth Nexus: Evidence From Emu Countries", International Review Of Economics And Finance 51, 470-486

Greenidge K., Drakes L., Craigwell R., (2010), “The External Public Debt in The Caribbean Community", Journal Of Policy Modeling 32, 418-431

Gül E., Kamac1 A., Konya S., (2012) “Effect Of External Debt On Growth: The Case Of Central Asian Republics And Turkey “, International Conference On Eurasian Economies, Kazakistan, 11-13.

Jayaraman T. K., Lau E., (2009), “Does External Debt Lead To Economic Growth in Pacific Island Countries", Journal Of Policy Modeling 31, 272-288

Kharusi A. S., Ada M. S., (2018), "External Debt and Economic Growth: The Case of Emerging Economy", Journal of Economic Integration, Vol. 33, 1141-1157.

Karagoz M., Caglar M., (2015) "Does Debt Really Crack The Whip? Evidence From A Panel Of Selected Oecd Countries", Istanbul Conference Of Economics And Finance, Icef 2015, 22-23 October 2015, Istanbul, Turkey

Kraay A., Nehru V., (2006), “When Is External Debt Sustainable?”, The World Bank Economic Review, Vol. 20, No. 3, Pp. 341-365

Ljirshar V. U., Joseph F., Godoo M., (2016) “The Relationship Between External Debt And Economic Growth In Nigeria", International Journal Of Economics \& Management Sciences, Sci 2016, 6:1

Metwally M. M., Tamaschke R., (1994), “The Foreign Debt Problem Of North African Countries”, African Review Of Money Finance And Banking, No. 1/2, Pp. 109-122

Muhanj1 S., Ojah K., (2011), “External Shocks And Persistence Of External Debt in Open Vulnerable Economies: The Case Of Africa", Economic Modelling 28, 1615-1628

Musibau H. O., Mahmood S., Ismail S., Shamsuddin Z., Rashid N., (2018), “Does External debt cause economic growth: An experience from ECOWAS member countries", Vol. 8, No. 11, 1256-1264.

Obudah, B.C. And Tombofa, S.S., (2013), “Effects Of Interest Rate And Debt On Equity Investment”. American Journal Of Humanities And Social Sciences. Vol. 1.

Panızza U., Presbitero A.F., (2014), "Public Debt And Economic Growth: Is There A Causal Effect?", Journal Of Macroeconomics 41, 21-41

Pesaran, Hashem M.; Shin, Yongcheol And Smith, Richard J., (2001), Bounds Testing Approaches To The Analysis Of Level Relationships, Journal Of Applied Econometrics, Vol.16, Pp. 289-32 
Prasad D., Rath B. N., (2014), "Public Debt And Economic Growth in India: A Reassessment", Economic Analysis And Policy 44, 292-300

Ramzan M., Ahmad E., (2014), "External Debt Growth Nexus: Role Of Macroeconomic Polices", Economic Modelling 38, 204-210

Semmlera W., Tahrı I., (2017), “Current Account Imbalances: A New Approach To Assess External Debt Sustainability", Economic Modelling 62, 161-170

Sen S., Kasıbhatla K.M., Stewart D. B., (2007), “Debt Overhang And Economic Growth-The Asian And The Latin American Experiences", Economic Systems 31, 3-11

Siddique A., Selvanathan E.A., Selvanathan S., (2016), “The Impact Of External Debt On Growth: Evidence From Highly İndebted Poor Countries", Journal Of Policy Modeling 38, 874-894

Singh C., (1999) "Domestic Debt And Economic Growth İn India", Economic And Political Weekly, Vol. 34, No. 23, Pp. 1445-1453

Spilıotı S., Vamvoukas G., (2015), “The Impact Of Government Debt On Economic Growth: An Empirical Investigation Of The Greek Market", The Journal Of Economic Asymmetries 12, $34-$ 40

Stella M.A., Godwin U., Osmond A. C., (2016) "Impact Of External Debt On Economic Growth In Nigeria: An Ardl Bound Testing Approach", Journal of Economics and Sustainable Development, Vol:7, 16-26, 2016

Teles V. K., Mussolını C. C., (2014), "Public Debt And The Limits Of Fiscal Policy To Increase Economic Growth", European Economic Review 66, 1-15

Umaru, A. Hamidu, A.A, And Musa, S., (2013)." External Debt And Domestic Impact On The Growth Of The Nigerian Economy." International Journal Of Educational Research.

Uysal D., Özer H., Mucuk M., (2009), " Dış Borçlanma Ve Ekonomik Büyüme İlişkisi: Türkiye Örneği (1965-2007)", Atatürk Üniversitesi İktisadi Ve İdari Bilimler Dergisi, Cilt: 23, Say1: 4, 2009

Wijnbergen S., (1991), "Debt Relief And Economic Growth in Mexico", The World Bank Economic Review, Vol. 5, No. 3 , Pp. 437-455. 